\title{
[ [69:]
}

XXIV, Copy of the Draught of a Proclamation in the. Vear $\mathbf{5}_{56} \mathbf{5}_{3}$, relating to Perfons making Portrait's of Queen Elizabeth. From the Original Draught in the Paper Office, in the Hand-writing of Secretary Cecil, woith bis Corrections, and among bis Papers: Communicated by Sir Jofeph Ayloffe, Bart.

Read at the Society of Antiluaries; Feb. 25, I768.

7 Orafmuch as thrugh the natural defire that all forts of 1 fubjects and people, both noble and mean, have to procure the portrait and pieture of the Queen's Majeftie, great nomber of Paynters, and fome Printers and Gravers, have allredy, and doe dayly attempt to make in divers manners portraietures of hir Majeftie in paynting, graving, and pryntyng, wherein is evidently thewn that hytherto none hath fufficiently expreffed the naturall reprefentation of hir Majefties perfon, favor, or grace, but for the moft part have alfo erred therein, as thereof dayly complaints are made amongft hir Majefties loving fubjects, in fo much that for redrefs hereof hir Majestie hath lately bene fo. inftantly and fo importunately fued unto by the Lords of hir Confell and others of hir nobility, in refpect of the gret diforder herein ufed, not only to be content that fome fpeciall coning payntor might be permitted by acceis to hir Majente to take the natural reprefentation of hir Majeltie whereof the hath bene allwife of hir own right difpofition very unwillyng, but allo to prohibit all manner of other perfons to draw, payn, srave, or pourtrayit hir Majefties perfonage os vifage for a time, unth by fome perfect patron and example the fame may be by others followed.

$$
\text { Vol. II. }
$$


¿990 Proclametion relating" to Portraits of 2 ueen Elizabeth.

ThERFOr hir Majeftie being herein as it were overcome with the eontynuall requeits of fo many of hir Nobility and Lords, whom The cannot well deny; is pleafed that for thir contentations, fome coning perfon mete therefor, thall thortly make a pourtraict of hir perfon or vifage to be participated to others for fatisfaction of hir loving fubjects, and furdermore commandeth all manner of perfons in the mean tyme to forbear from payntyng, graving, printing, or making of any pourtraict of hir Majeftie, until fome fpeciall perfon that thall be by hir allowed thall have firft finifhed a pourtraicture thereof, after which fynifhed, hir Majeftie will be content that all other painters, printers, or gravers, that thall be known men of underftanding, and fo thereto licenfed by the hed officers of the plaices where they thall dwell (as reafon it is that every perfon thould not without confideration attempt the fame) Thall and maye at their pleafures follow the fayd patron or firft portraicture. And for that hir Majeftie perceiveth that a grete nomber of hir loving fubjects are much greved and take great offence with the errors and deformities allredy committed by fondry perfons in this behalf, the ftraightly chargeth all hir officers and minifters to fee to the due obfervation hereof, and as foon as may be to reform the errors already committed, and in the mean tyme to forbydd and prohibit the Phewing or publication of fuch as are apparently deformed, until they may be reformed which are reformable. 